Farhat. et al. Rhinosinusitis Identification And Training Of Cardes In Medan Area District

\title{
RHINOSINUSITIS IDENTIFICATION AND TRAINING OF CADRES IN MEDAN AREA DISTRICT
}

\author{
Farhat $^{1}$, E. Rahmi Daulay ${ }^{2}$ \\ ${ }^{1}$ Department of Otorhinolaryngology Head and Neck Surgery - Faculty of Medicine, Universitas Sumatera Utara, \\ Medan, North Sumatera, Indonesia \\ ${ }^{2}$ Department of Radiology - Faculty of Medicine, Universitas Sumatera Utara, Medan, North Sumatera, \\ Indonesia
}

\begin{abstract}
Objective : Chronic rhinosinusitis is an inflammation of the nasal mucosa and paranasal sinuses established based on a history of rhinosinusitis lasting more than 12 weeks. Rhinosinusitis may be caused by allergies, infections and anatomical structural abnormalities or other causes such as idiopathic, nasal, hormonal, drugs, irritant, fungi, emotions, atrophy. Lingkungan VIII and X Kelurahan Tegal Sari I Medan Area District was selected as a community service partner based on location and environment characterized.

Method : We trained the cadres to know rhinosinusitis and we screened the population to do early detection of the disease.

Result : From 100 patients who came, 56\% of them are males, with most age $21-25$ years as many as $36 \%$, while the main complaint was runny nose as many as $43 \%$.
\end{abstract}

Keywords: chronic rhinosinusitis, community service, cadres' training

\section{INTRODUCTION}

Chronic rhinosinusitis is an inflammation of the nasal mucosa and paranasal sinuses established based on a history of rhinosinusitis lasting more than 12 weeks. Prevalence of the disease varies. In Canada, chronic rhinosinusitis was more detected in males more than females, with the prevalence increase along with age, in the group age between 20-29 and 50-59 years old (Fokkens et al., 2012). In dr. Sardjito hospital Yogyakarta between 2000-2006 the frequency of chronic rhinosinusitis patients was around 2,5$4,6 \%$ from all outpatient clinic (Harowi et al., 2011).

Etiology of Rhinosinusitis may be caused by allergies and infections. It also may be caused by anatomical structural abnormalities (ostiomeatal complex variation, septum deviation, concha hypertrophy) or other causes such as idiopathic, nasal, hormonal, drugs, irritant, fungi, emotions, atrophy (Kennedy \& Lee, 2001; Fokkens et al., 2012). Some pathogenic bacteria that frequently connected with the etiology of chronic rhinosinusitis were Staphylococcus aureus, Pseudomonas aeruginosa, Hemophilus influenza and Moraxella catarrhalis (Fokkens et al., 2012). The most common etiology of chronic rhinosinusitis is rhinogenic, which is the expansion from the nose infection. The lingering infection of the sinus called as chronic rhinosinusitis, with the most common etiology of the disease is the failure of the acute phase to recover (Dhingra, 2014).

Chronic rhinosinusitis diagnosed from anamnesis, physical and supporting examination (Busquets et al., 2006). History of the symptoms lasting more than 12 weeks, and based on two major symptoms or 1 major plus two minor symptoms from the sign and symptoms according to Rhinosinusitis Task Force, 2006. The major symptoms are; facial pain, nasal blockage, purulent mucous, and smell disorder. Minor symptoms are; headache, fever, halitosis, toothache, and cough (Busquets et al., 2006; Fokkens et al., 2012).

Based on European Position Paper on Rhinosinusitis and Nasal Polyps (2012), the chronic rhinosinusitis symptoms are nasal blockage $(83,7 \%)$, facial pain $(64,7 \%)$, runny nose $(63,7 \%)$ and smell disorder $(48,5 \%)$. Rhinosinusitis complication rarely occurs after the antibiotics treatments. However, in malnutrition low social-economic population and unreachable by the healthcare facility, the rhinosinusitis complication often occurred even 
Farhat. et al. Rhinosinusitis Identification And Training Of Cardes In Medan Area District

causing blindness and death. The complications are an orbital and intracranial disorder, mucocele (cyst), and lung disorder. The main aim of chronic rhinosinusitis treatment is to decrease sign and symptoms, increase the quality of life and prevent the relapse and progressiveness of the disease (Scadding, 2009).

We chose the Lingkungan VIII and $\mathrm{X}$ Kelurahan Tegal Sari 1 Medan Area District, Medan City as a partner of community service based on the consideration of the location characteristic and local community such as crowded environment and low level of education. The crowded environment of both areas is causing a low level of health status and lack of motivation to check their medical condition added with the fact that they have to miss out their work due to attend ENT medical checkup.

The target of training and screening in this community service are the people in Lingkungan VIII and $\mathrm{X}$ with rhinosinusitis symptoms, while the health cadres will get some training about rhinosinusitis and early detection of the disease.

The output of this training and community service are to increase awareness and lowering the incidence of chronic rhinosinusitis in partner community neighborhood, ability to do early detection, decreasing the morbidity and mortality number due to this disease and motivating the community to prevent actively and early detect the chronic rhinosinusitis.

\section{METHODS}

The implementation method offered from the community service program is divided into several stages, which are a review of partner area locations and with the head of the environment, education on chronic rhinosinusitis by counseling methods to cadres and later on will become the spearhead for chronic rhinosinusitis early detection activity. The educational materials are the definition of chronic rhinosinusitis, etiology, sign and symptoms of chronic rhinosinusitis, ENT examination to diagnose chronic rhinosinusitis, complication of chronic rhinosinusitis and also the treatment. We did the ENT examination, chronic rhinosinusitis detection, and also supporting examination like paranasal sinus $\mathrm{x}$-ray. Interpretation of the examination results will help to decide which patients will be referred to a better health facility for appropriate management.

\section{RESULT}

Rhinosinusitis detection community service and cadres training were held in Lingkungan VIII and $\mathrm{X}$ Kelurahan Tegal Sari Medan Area District, Medan City. The screening of rhinosinusitis patients results as seen in table 1 .

Table 1.Patients characteristics in Lingkungan VIII and X

\begin{tabular}{lrr}
\hline Characteristics & n & $\%$ \\
\hline Gender & & \\
Male & 56 & 56 \\
Female & 44 & 44 \\
\hline Age (years old) & & \\
$<15$ & 9 & 9 \\
$15-20$ & 9 & 9 \\
$21-25$ & 36 & 36 \\
$25-30$ & 12 & 12 \\
$31-35$ & 7 & 7 \\
$35-40$ & 9 & 9 \\
$>40$ & 18 & 18 \\
\hline Main Complaint & & \\
Nasal blockage & 36 & 36 \\
Runny nose & 43 & 43 \\
Headache & 1 & 1 \\
Smell disorder & 7 & 7 \\
Sneezing & 3 & 3 \\
Throat sputum & 0 & 0 \\
Others & 10 & 10 \\
\hline
\end{tabular}

As seen in table 1, among 100 patients most of them are male (56\%), the most common age is between 21-25 years old (36\%), and the most common complaint which brought the patients seek for therapy is a runny nose $(43 \%)$.

Table 2. Patients are characteristic in Lingkungan VIII and $\mathrm{X}$ based on gender, physical examination, and paranasal sinus X-ray.

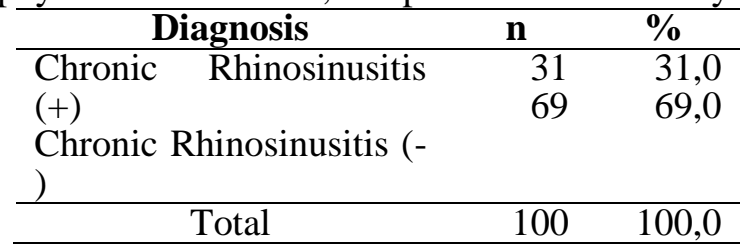


Farhat. et al. Rhinosinusitis Identification And Training Of Cardes In Medan Area District

As seen from the table 2, 100 patients who came to seek therapy, diagnosed with chronic rhinosinusitis based on anamnesis and sinus paranasal X-ray are 31 patients $(31 \%)$, not rhinosinusitis $(69 \%)$.

Table 3. Chronic rhinosinusitis patients distribution in Lingkungan VIII and X based on gender.

\begin{tabular}{|c|c|c|}
\hline $\begin{array}{l}\text { Chronic Rhinosinusitis } \\
\text { Patients }\end{array}$ & n & $\%$ \\
\hline Male & 16 & 51,6 \\
\hline Female & 15 & 48,4 \\
\hline Total & 100 & 100,0 \\
\hline
\end{tabular}

As seen from table 3 , there is 31 people diagnosed with chronic rhinosinusitis $16(51,6)$ of them are males, and $15(48,4 \%)$ are females.

\section{DISCUSSION}

Training of cadre was conducted on ten cadres representing Lingkungan VIII and X Kelurahan Tegal Sari I Medan Area Subdistrict. The training took place at Puskesmas Sukaramai containing materials about chronic rhinosinusitis disease, signs, and symptoms, management and prevention. The level of cadre understanding was also evaluated through the questionnaire given after the completion of the materials. From the ten trained cadres, eight cadres $(80 \%)$ were able to answer the questionnaire correctly.

Chronic rhinosinusitis is a chronic disease that includes long-term inflammation of the nasal mucosa and paranasal sinuses. This situation is very common, according to the National Health Interview Survey of 1996, chronic rhinosinusitis is the second disease that affected health, affected $12.5 \%$ of the total population or 31 million people in the United States per year (Hamilos, 2011). According to the European Position Paper on Rhinosinusitis and Nasal Polyps (2007), chronic rhinosinusitis as inflammation of nasal and paranasal sinuses characterized by the presence of two or more symptoms. One of which should be a nasal blockage/obstruction/congestion or a runny nose (anterior/posterior nasal secretions), facial pain/depression on the face, decrease/loss of smell, lasting more than 12 weeks.

(Table 1). The most common gender is male as much as 56 patients $(56 \%)$, the largest age group is in the age group of 21-25 years as much as 36 patients $(36 \%)$. According to table 3 was found, 100 patients. 31 patients diagnosed with chronic rhinosinusitis, the most frequently is male as much as 16 people $(51,5 \%)$, while woman as much as 15 people $(48,4 \%)$.

In Canada, men are more likely to suffer chronic rhinosinusitis than women, where the prevalence of chronic rhinosinusitis increases with age, which increases in the 20-29 and 50-59 years age group (Fokkens et al., 2012). According to Dewi (2013), 111 chronic rhinosinusitis patients underwent a functional endoscopic sinus surgery in H. Adam Malik General Hospital Medan, in which the most age group was in 15-24 years. Munir (2006), in his study, found the most age group was 35-44 years as many as $34.3 \%$, while female patients as many as 20 patients $(57 \%)$ and male as many as 15 patients $(43 \%)$.

The most common patient's main complaint is a runny nose as much as 43 patients (43\%), followed by nasal congestion complaints as much as 36 patients (36\%). Dewi (2013) research on 53 patients obtained the most major symptom is mucopurulent rhinorrhea (83\%), nasal obstruction $(81,1 \%)$, Posterior Nasal Drip $(81,1 \%)$, and nasal discharge $(67,9 \%)$ and the most common minor symptom is headache (90.6\%).

There are many risk factors can cause chronic rhinosinusitis. IgE-mediated allergic prevalence of allergen environments in patients with chronic rhinosinusitis is estimated at $60 \%$ compared with $30 \%$ to $40 \%$ of the population. Patients with chronic rhinosinusitis are usually sensitive to seasonal allergens (pollen). Other allergens include house dust mites, fungal spores from the inside and outer room, animal dander, cockroaches. These allergens are commonly found at higher levels for longer periods of time compared to pollen allergens. Fungal spores can grow in sinus mucus, resulting in increased allergic stimuli (Berrettini, 1999). According to National Health and Nutrition Surveys (19881994) of 33,994 people, there was a relation between chronic sinusitis with both active and passive smokers (Lieu, 2000). 


\section{CONCLUSION}

Among 100 patients who came to Puskesmas, there were 31 patients $(31 \%)$ diagnosed with chronic rhinosinusitis.

\section{REFERENCE}

Berrettini S, Carabelli A, Sellari-Franceschini S, Bruschini L, Abruzzese A, Quartieri F, et al. Perennial allergic rhinitis and chronic sinusitis: correlation with rhinologic risk factors. Allergy 1999;54:242-8.

Busquets JM, Hwang PH, 2006. Non Polypoid Rhinosinusitis; Classification, Diagnosis and Treatment. In: Bailey BJ, Head and Neck Surgery Otolaryngology. $4^{\text {th }}$ Edition. Vol 2. Philadelphia: Lippincot Williams \& Wilkins. p: 405-16.

Dewi, E 2013, Profil rinosinusitis kronik di RSUP H. Adam Malik Medan Tahun 20082011, Tesis Program Magister Kedokteran Klinik Ilmu Kesehatan THT-KL FK USU, Medan

Dhingra PL, 2014. Anatomy and Physiology of Paranasal Sinuses, p: 178-91
Fokkens W et al., 2012. European Position Paper on Rhinosinusitis and Nasal Polyps 2012. Rhinology 2012; suppl 23:1-298.Hamilos D, 2011. Chronic rhinosinusitis: Epidemiology and medical management. Clinical reviews in allergy and immunology; p.1-15

Harowi dkk, 2011. Kualitas Hidup Penderita Rinosinusitis Kronik Paska-bedah. CDK 187/ vol. 38 no.6. Hal 429-34.

Kennedy DW, Lee JT, 2001. Endoscopic Sinus Surgery, in Head and Neck surgeryOtolaryngology, Vol II, Third Edition, Byron J. Bailey Lippincott Williams and Wilkins, Philadelphia. p: $459-75$.

Lieu JE, Feinstein AR. Confirmations and surprises in the association of tobacco use with sinusitis. Arch Otolaryngol Head Neck Surg 2000;126:940-6.

Munir, 2006, Variasi Anatomi pada Rinosinusitis Kronis di RS H. Adam Malik Medan. Majalah Kedokteran Nusantara Volume 39. No. 3. h.225-9.

Scadding G. Medical Management of Chronic Rhinosinusitis. In Scott-Brown's Otorhinolaryngology, Head and Neck Surgery. Volume 2. Hodder Arnold an Hachette UK Company, London. p:1469-76 